\title{
The human intestinal IgA response; burning questions
}

\section{Jo Spencer *, Linda S. Klavinskis and Louise D. Fraser}

Peter Gorer Department of Immunobiology, King's College London School of Medicine at Guy's King's College and St. Thomas' Hospitals, London, UK

\section{Edited by:}

Nils Yngve Lycke, University of Gothenburg, Sweden

Reviewed by:

Emma Slack, Universität Bern, Switzerland

Nicholas J. Mantis, New York State

Department of Health, USA

*Correspondence:

Jo Spencer, Peter Gorer Department

of Immunobiology, King's College

London School of Medicine at Guy's

King's College and St. Thomas'

Hospitals, London, UK.

e-mail: jo.spencer@kcl.ac.uk
The title of this special topic invites us to identify areas in the field of IgA biology that are uncertain or in need of clarification. The inductive phase of the human intestinal IgA response has been a controversial area for some years. Therefore, to structure this review, we have identified key questions that are debated in this field. We have provided explanations of the origins of the uncertainties and have provided our own reasoned answers to the questions we pose.

Keywords: human, IgA, gut-associated lymphoid tissue
Secretion of a huge quantity of IgA with a diverse antigen-binding repertoire is essential for the maintenance of intestinal homeostasis and the prevention of mucosal and systemic infection (Conley and Delacroix, 1987; Brandtzaeg et al., 1999; Wei et al., 2011). Most of this IgA is secreted by the vast plasma cell population, which is located beneath the intestinal epithelium throughout the gastrointestinal tract.

Many of the questions that continue to perplex those working in the field of mucosal B cell biology, and confuse those outside, relate to the biology of intestinal B lineage cells prior to terminal differentiation into plasma cells. Problems in providing secure answers derive from inherent difficulties in studying the human intestinal immune system. Difficulties extend beyond the obvious restrictions to sampling tissue, and the existence of some basic species differences (Gibbons and Spencer, 2011). Some difficulties are exemplified by the earliest experiments that defined this field. For example, Gowans and Knight (1964) showed that the thoracic duct lymph of rats contains a continuous flow of immunoblasts without the need for prior immunization (Gowans and Knight, 1964). These gut-derived activated cells were destined for the blood. Adoptive transfer of labeled cells demonstrated that thoracic duct immunoblasts were pre-programmed to home back to the intestine by selective extravasation through the capillary network. This demonstrated not only that the intestinal immune system is a distinct entity, but also that understanding the immunology of the IgA response would require an appreciation of immune physiology and anatomy because multiple anatomically separated sites and structures were involved, connected by lymph and the blood. It is particularly difficult to study such a system definitively in humans.

Understanding current perception of the intestinal B cell response initially requires appreciation of the anatomical and microanatomical sites involved, and the associated terminology (Brandtzaeg and Pabst, 2004; Brandtzaeg, 2009). The intestinal immune system can be divided into organized gut-associated lymphoid tissue (GALT), the lamina propria, the intraepithelial compartment, and the regional lymph nodes.

Gut-associated lymphoid tissue (Figure 1) is organized lymphoid tissue with discrete $\mathrm{B}$ and $\mathrm{T}$ cell zones, that is, by definition intimately associated with a specialized follicle associated epithelium (FAE). The "microfold" or "M" cells of the FAE selectively sample particulate antigen from the gut lumen and transport it to the underlying lymphoid tissue (Chabot et al., 2006) forming a discriminatory gatekeeper function, but also a connection with the luminal microbiota. The Peyer's patches are aggregates of GALT that are most concentrated in the terminal ileum. Isolated follicles of GALT as will be discussed below are also located throughout the small and large intestines.

In contrast, the lamina propria comprises diffuse connective tissue with a lymphoid component that includes largely effector cells; both cytokine-producing $\mathrm{T}$ cells and plasma cells (Farstad et al., 2000). The vast majority of B cells in lamina propria are CD19+, CD20-, and these cells are almost certainly the extravasated immunoblasts en route to terminal differentiation to plasma cells. The lamina propria is sited below an epithelial barrier, which in contrast to the FAE is secured by tight junctions and covered by a layer of mucins and microbicidal molecules on the luminal aspect (Turner, 2000).

The intraepithelial lymphoid compartment (other than the FAE associated lymphocytes) does not include many B cells, and is not relevant to this review. The mesenteric lymph nodes on the other hand contain and abundance of active B cells and the scale of their involvement in human intestinal immunity is not known (Figure 2).

A major goal in human intestinal immunity must be to deduce how the IgA response can be harnessed for mucosal vaccination. Understanding the rules that govern the generation and dissemination of the antigen-specific plasma cells in the intestine would move us considerably further toward that goal, though there are still many areas that lack clarity. Table $\mathbf{1}$ comprises a list of current 


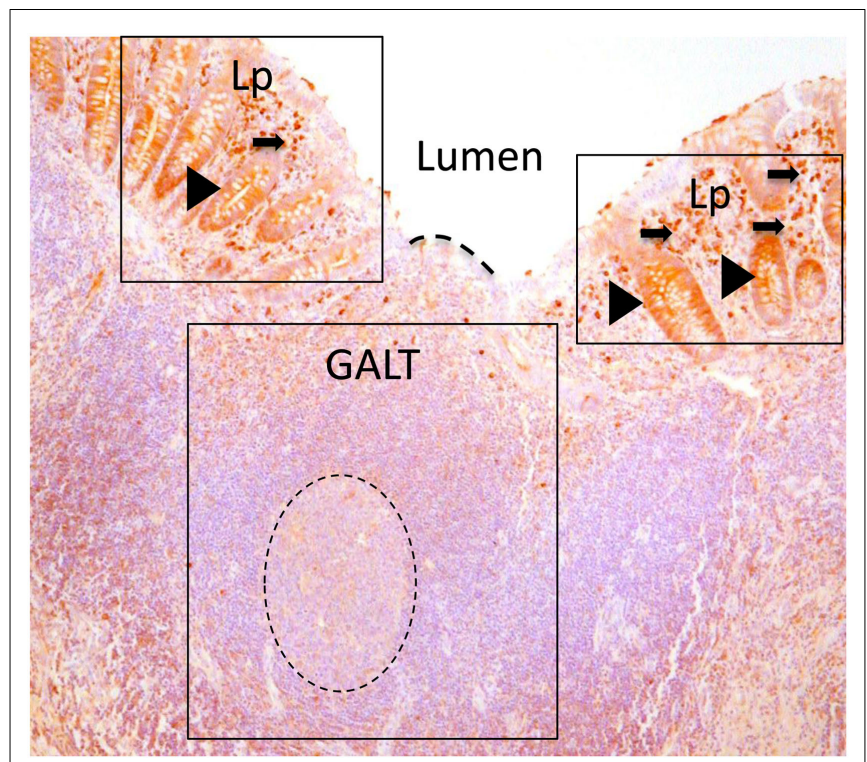

FIGURE 1 | Paraffin sections of human appendix stained to detect IgA (brown). Gut-associated lymphoid tissue (GALT) is boxed. GALT is comprised mostly of B cells and contains a prominent germinal center of dividing $B$ cells (dotted circle). The epithelial barrier between the GALT and the intestinal lumen, marked with a dotted line, is the FAE. Lamina propria $(L p)$ is boxed either side of GALT. The lamina propria includes abundant effector cells including plasma cells (arrowed) Unlike the epithelium adjacent to GALT, crypt epithelium of the lamina propria contains IgA that is in the process of being transported to the intestinal lumen (arrow heads).

questions that relate to the human intestinal immune response that might be answered unambiguously in the near future. The questions are accompanied by our own simple best answers. The final column is our measure of faith in our answer. Our reasoned responses to the questions and rationale behind the answers comprise the text of this review.

\section{DO THE EVENTS THAT INITIATE THE HUMAN IgA RESPONSE OCCUR EXCLUSIVELY IN GUT-ASSOCIATED LYMPHOID TISSUE?}

It is clear from simple histological observations that GALT is an inductive site for intestinal B cell responses. The Peyer's patches invariably have prominent germinal centers of dividing B cells. Dividing cells are also apparent in the large marginal zone that forms the outermost B cell area of GALT (Boursier et al., 2005). Suggestion that lamina propria might be an inductive site followed a high profile study of cell suspensions prepared from the intestines of mice with the Peyer's patches removed (Fagarasan et al., 2001). This work identified that the enzyme activationinduced cytidine deaminase (AID), the essential catalyst of class switch recombination and somatic hypermutation, was present in the isolates. Several years later, it was proved that GALT is required for the IgA response, and that the features of the inductive phase of the IgA response ascribed to lamina propria cells was in fact a consequence of contamination of the isolates by cells from the organized GALT in isolated lymphoid follicles (ILF). The isolated follicles are not macroscopically visible, and are developmentally

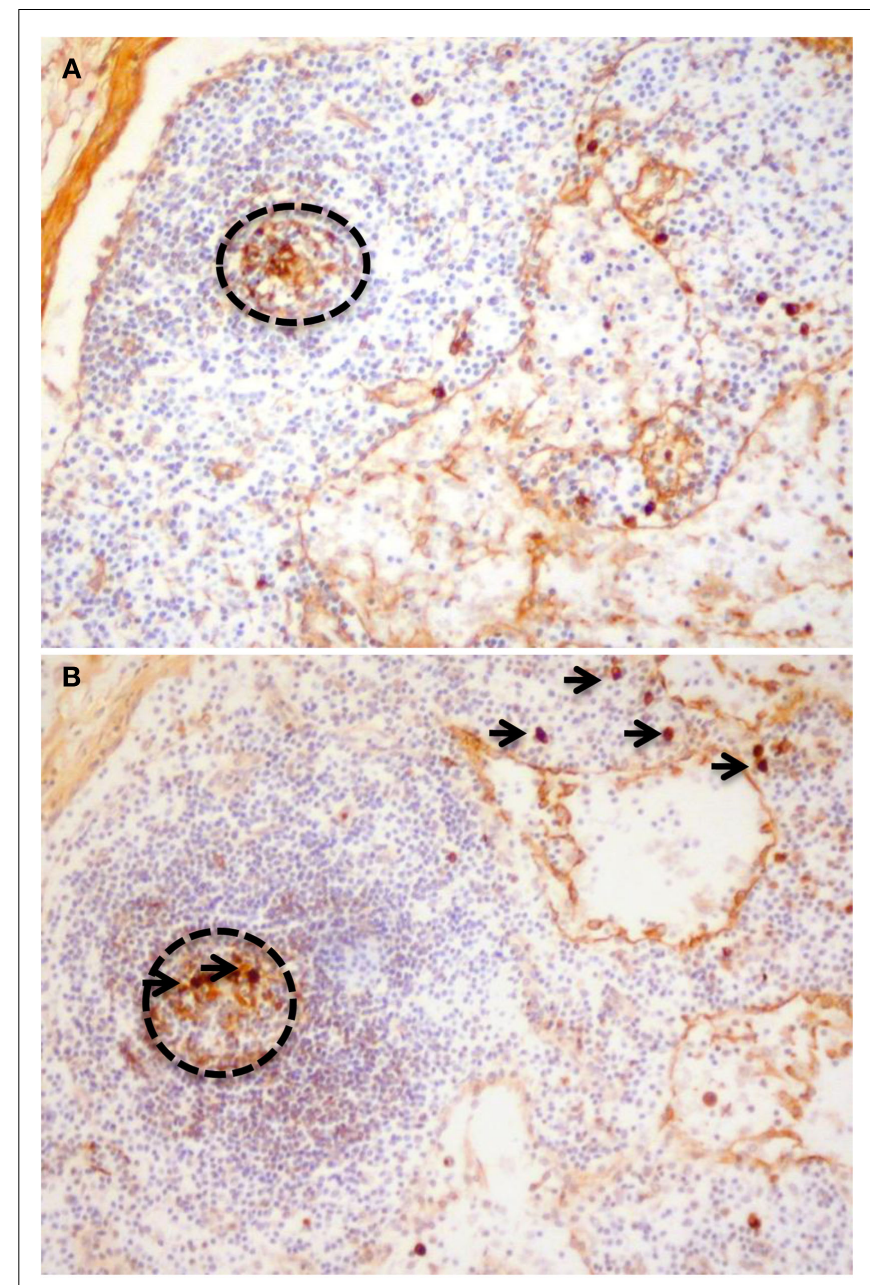

FIGURE 2 | Paraffin sections stained to detect (A) IgA1 and (B) IgA2.

Cells with cytoplasmic immunoglobulin of both subclasses can be observed in germinal centers (dotted circles) demonstrating that the mesenteric nodes could be classified as a non-GALT site of induction for IgA responses. The presence of cells with cytoplasmic IgA2 in mesenteric nodes (arrows) also demonstrates that switching to IgA2 is not only a feature of terminal differentiation in the colonic lamina propria.

independent of the Peyer's patches (Tsuji et al., 2008; Lindner et al., 2012). Meanwhile the concept of lamina propria as an inductive site had gathered momentum and has been documented in reviews (Cerutti, 2008a; Suzuki and Fagarasan, 2009).

It has been suggested that IgA class switch recombination to IgA2 can occur in human colonic lamina propria, driven by the IgA switch factor a proliferation-inducing ligand (APRIL) produced by epithelia in response to TLR 5 ligation by colonic luminal bacteria (He et al., 2007). Although this idea provides an elegant explanation for the relatively higher frequency of plasma cells synthesizing the IgA2 subclass in colon (Kett et al., 1986; Kett and Brandtzaeg, 1987), it has been contested by groups that give full consideration to the lymphoid microenvironments in intestine. The study of both mouse and human lamina propria cells that were sampled from tissue sections in situ, or isolated plasma cells did not detect the expression of AID in lamina propria of large or 


\begin{tabular}{|c|c|c|}
\hline Question & $\begin{array}{l}\text { Authors' best } \\
\text { guess answer }\end{array}$ & $\begin{array}{l}\text { Degree of certainty } \\
\text { in answer }(\%)\end{array}$ \\
\hline Do the events that initiate the human IgA response, occur exclusively in gut-associated lymphoid tissue? & Yes & 90 \\
\hline Is there an equivalent of murine cryptopatch precursor of ILFs in humans? & No & 95 \\
\hline Can gut-associated lymphoid tissue be acquired in response to bacterial antigens in humans? & Yes & 100 \\
\hline Are there $T$ cell dependent and $T$ cell independent routes to IgA production in man? & Yes & 95 \\
\hline $\begin{array}{l}\text { Are intestinal T cell dependent IgA responses, necessarily dependent on conventional cognate } \\
\text { interactions in humans? }\end{array}$ & No & 60 \\
\hline Do innate receptors have any role in driving the human mucosal IgA response? & Yes & 100 \\
\hline $\begin{array}{l}\text { Might germinal centers be involved in both T cell dependent and T cell independent IgA responses in } \\
\text { humans? }\end{array}$ & Yes & 95 \\
\hline Are there differences in the induction of IgA responses that seed the small bowel and the colon? & Yes & 70 \\
\hline Is the human intestinal IgA response antigen specific? & Yes & 100 \\
\hline Is light chain drifting a feature of the IgA response? & Yes & 100 \\
\hline Is there local proliferation of plasma cell precursors in the human intestinal lamina propria? & No & 90 \\
\hline Are human intestinal IgA plasma cells long lived? & Yes & 90 \\
\hline
\end{tabular}

small intestine (Boursier et al., 2005; Bergqvist et al., 2006, 2010; Di Niro et al., 2012). Class switch recombination also requires cell division; a process that has not been observed in lamina propria cells directly (Boursier et al., 2005; see Is there Local Proliferation of Plasma Cell Precursors in the Human Intestinal Lamina Propria?). Cells in germinal centers of mesenteric lymph nodes can express IgA2, again, consistent with class switch to IgA2 prior to homing to the lamina propria environment (Figure 2).

It was suggested that the lamina propria $\mathrm{B}$ cell response may be initiated by antigens sampled by dendritic cells (DC) that extend processes through the epithelium (Rescigno et al., 2001; Niess et al., 2005). It was also suggested that the lamina propria B cell response in mice might involve the $\mathrm{B} 1$ lineage (Kroese et al., 1989). However, it is now apparent that the lamina propria in mice and humans may not be so different, with most having features exclusively of effector niches. The DCs that take up antigen from the lumen do not mediate antigen presentation in the lamina propria, but transfer antigen to DCs that mediate their function in the mesenteric lymph nodes (Pabst et al., 2007; Pabst and Mowat, 2012).

The exclusivity of GALT as an inductive site is not correct if the contribution of the mesenteric lymph node is considered, hence the lack of certainty in Table 1. GALT is defined in part by its relationship to the intestinal epithelium; so mesenteric lymph node is therefore potentially a non-GALT inductive site (Brandtzaeg and Pabst, 2004). Human mesenteric nodes are immunologically active structures containing germinal centers that could represent initiation or amplification of human intestinal B cell responses (Figure 2). It would most accurate to say that the human IgA response is generated in organized lymphoid tissue, and that the lamina propria is not an inductive site.

\section{IS THERE AN EQUIVALENT OF MURINE CRYPTOPATCH PRECURSOR OF ILFS IN HUMANS?}

Cryptopatches of mice are small isolated clusters of lymphoid progenitors located around the base of the small intestinal crypts (Kanamori et al., 1996). Engagement of epithelial NOD1 innate receptors by bacteria from the intestinal lumen initiates the development of ILF from cryptopatch precursors (Bouskra et al., 2008). GALT acquired in this way in mice exists as single isolated follicles that are invisible to the naked eye, rather than the macroscopically visible clusters of lymphoid tissue that comprise murine Peyer's patches.

One problem in addressing the question of whether humans have cryptopatches or even a direct equivalent of ILF is that GALT in humans, in general, is either invisible or just visible to the naked eye. GALT can be visualized from the luminal aspect in humans by injecting dye into the mucosa, by fixation or by using magnification (Cornes, 1965). GALT in normal human small intestine can exist as large clusters, small clusters or isolated follicles in the small bowel and each of these categories appears to be structurally and developmentally equivalent (Figure 3), and not necessarily to be associated differently with the microbiota in the intestinal lumen.

In their search for cryptopatches, Moghaddami et al. (1998) described lymphocyte filled villi; clusters of lymphocytes within a villus structure. The significance of these structures, that are not rare, remains unknown. The current consensus is that humans do not have cryptopatches (Moghaddami et al., 1998; Brandtzaeg, 2010), but it is possible that they exist during a small window in time just after birth, though they are still to be discovered.

\section{CAN GUT-ASSOCIATED LYMPHOID TISSUE BE ACOUIRED IN RESPONSE TO BACTERIAL ANTIGENS IN HUMANS?}

Probably the clearest example of acquisition of GALT in humans in response to bacteria is the acquisition of GALT in the stomach in response to the gastric bacterial pathogen Helicobacter pylori (Wotherspoon et al., 1991). Normal stomach is rich in mucus and acid and is generally sterile in health (Williams, 1992; Mobley, 1996). The lamina propria underlying the gastric epithelium contains a sparse infiltrate of lymphoid and myeloid cells and there is no GALT. H. pylori is able to colonize the stomach by neutralizing the acidic microenvironment by the production of 




FIGURE 3 | (A,B) Frozen sections of human fetal intestine of 22 weeks of gestation. (A) Is stained with CD3 (T cells in brown) and CD20 (B cells in blue). (B) Is stained for CD3 (T cells in brown) and CD5 (B cells in blue since human fetal $B$ cells are CD5+). Follicles in clusters in (A) or as ILF in (B) are the same in terms of the cellular composition and stage of development. Paraffin sections of human intestine at 4 days old stained for cytoplasmic IgM. (C) Illustrates a cluster of follicles in a Peyer's patch and (D) illustrates a single follicle that could be classified as an ILF. In (C,D), cytoplasmic $\lg \mathrm{M}+$ cells can be identified in the germinal center and on the periphery of the follicle and they appear very similar. There was very little IgA apparent in sections of either in stained serial sections. These images demonstrate that in human ileum there is no apparent developmental difference between follicles in clusters and isolated lymphoid follicles.

ammonia. Infection with $H$. pylori is relatively common and the gastritis associated with $H$. pylori infection invariably includes the acquisition of GALT.

Helicobacter pylori infection may be a causative contributor to gastric malignancy including lymphoma of mucosa-associated lymphoid tissue (MALT; Wotherspoon et al., 1993). Therefore pathologists are acutely aware of the changes in the gastric mucosa and the lymphoid cells it contains in response to $H$. pylori infection. If cryptopatches were involved in the development of acquired ILFs in human stomach in response to bacteria, they would almost certainly have been noticed. However, murine stomach is not necessarily equivalent to murine intestine in the biology of cryptopatches (Ishikawa et al., 1999) and this does not reflect on the issue of human cryptopatches as a whole, which remains unclear.

\section{ARE THERE T CELL DEPENDENT AND T CELL INDEPENDENT ROUTES TO IgA PRODUCTION IN MAN?}

The identification of $\mathrm{T}$ cell independent contributions to the human intestinal IgA response would not have been possible without examples in human disease phenotypes. For example, the subset of patients with hyper-IgM syndrome who have mutations in CD40 have intestinal IgA responses despite the inability to recruit cognate $\mathrm{T}$ cell help through CD40/CD40L interaction. This is also true in CD40-/- mice that have IgA plasma cells (Ferrari et al., 2001; Bergqvist et al., 2006, 2010; He et al., 2007; Cerutti et al., 2011). Consistent with a lack of germinal center formation however, for which cognate $\mathrm{T}$ cell interaction remains a prerequisite, there are no mutations in the immunoglobulin heavy chain variable region genes (IGHV; Bergqvist et al., 2006, 2010). A further example demonstrating that the $\operatorname{IgA}$ response is not necessarily $\mathrm{T}$ cell dependent in humans is the presence of an IgA response in individuals with severe $\mathrm{T}$ cell depletion or loss of germinal centers as a consequence of HIV infection (Levesque et al., 2009), though this response may be reduced, especially in the IgA2 subclass (Schneider et al., 1996; He et al., 2007).

Dendritic cells can produce APRIL that can support class switch recombination to IgA in the absence of T cell derived CD40 ligation (Fayette et al., 1997; Litinskiy et al., 2002; Cerutti, 2008b). Despite its name, APRIL is not specifically a B cell activating factor and its function as a switch factor in models of APRIL class switch function generally include additional elements such as an initiator of cell division and cytokine, for example IL4 (Hardenberg et al., 2007). In contrast, T cell dependent class switch to IgA involves ligation of CD40 on B cells by T cells expressing CD40L and binding of the cytokine TGF $\beta$ to its receptor on B cells (McIntyre et al., 1995; Zan et al., 1998).

It has been suggested, based on mouse models, that $\mathrm{T}$ cell dependent IgA responses are initiated in Peyer's patches, whereas $\mathrm{T}$ cell independent IgA responses occur in ILF (Suzuki and Fagarasan, 2009), though this may not be exclusive, particularly in the context of infection with viruses expressing highly repetitive antigenic determinants on their envelopes or capsids. The early murine immune response to rotavirus infection includes a T-independent IgA response (Franco and Greenberg, 1997; VanCott et al., 2001; Blutt et al., 2008), driven by a B cell/DC axis in Peyer's patches (Blutt and Conner, 2010). In humans, functional differences between Peyer's patches and ILFs are not yet apparent; both contain APRIL-secreting cells and cells expressing the receptors for APRIL; TACI; and BCMA (Barone et al., 2009). The colonic isolated follicles (lymphoglandular complexes; O'Leary and Sweeney, 1986) may have large, small, or undetectable germinal centers, and it is possible that colonic GALT may be different to GALT in the small bowel by having less dependence on cognate B cell/T cell interactions and germinal center formation (Garside et al., 1998). If confirmed, this may suggest a new avenue for mucosal vaccine design, facilitating induction of high affinity $\mathrm{IgA}+\mathrm{B}$ cells independent of strict cognate B cell/T cell signaling. Currently, enteric vaccine designs are largely focused on more conventional approaches to harness $\mathrm{T}$-dependent $\mathrm{B}$ cell pathways with the goal of stimulating IgA memory B cell responses, as illustrated by the live attenuated Shigella vaccines progressing through the clinic (Simon et al., 2011a). Sub-unit enteric vaccines can contain the outer membrane polysaccharide moiety of lipopolysaccharide (LPS; O-Ag), a major protective antigen of many Enterobacteria (Svenson et al., 1979; Rasolofo-Razanamparany et al., 2001; Levine et al., 2007). As such, polysaccharide antigens may purely drive T-independent IgA responses, though these are weakly immunogenic in infants (reviewed in Pollard et al., 2009; Renz et al., 2011). Nonetheless, considerable evidence demonstrates that conjugation of $\mathrm{O}-\mathrm{Ag}$ haptens to protein carriers successfully drives potent T-dependent responses both in mice (Phalipon et al., 2006; Simon et al., 2011b) and in humans (Passwell et al., 2003). 


\section{ARE INTESTINAL T CELL DEPENDENT IgA RESPONSES DEPENDENT ON CONVENTIONAL COGNATE INTERACTIONS IN HUMANS?}

Conventional $\mathrm{T}$ cell dependent $\mathrm{B}$ cell responses that result in the formation of germinal centers initially involve the endocytosis of antigens bound by the $\mathrm{B}$ cell receptor and presentation of peptides derived from them to pre-primed T cells (Garside et al., 1998). The firmest evidence for a lack of requirement for such cognate interaction in mucosal responses stems from a study in which the requirement for tonic signaling for B cell survival through the $\mathrm{B}$ cell receptor in a murine model was substituted by the latent membrane protein of Epstein Barr virus (EBV; Casola et al., 2004). These mice were unable to endocytose and present antigen, and therefore could not recruit $\mathrm{T}$ cell help and germinal centers did not form in the systemic lymphoid tissues. Interestingly however, germinal centers did form in the Peyer's patches and these were $\mathrm{T}$ cell dependent and also dependent on the luminal microflora.

Is there any evidence of possible disconnectivity between $\mathrm{B}$ cell and $\mathrm{T}$ cell specificity that also relates to humans? Human MALT lymphomas are malignancies of mucosal marginal zone $\mathrm{B}$ cells. The tumor cells are intimately associated with germinal centers and can enter, divide and differentiate in germinal centers (Isaacson and Spencer, 1987). The immunoglobulin specificities of MALT lymphomas have now been studied by many groups and a dominant reactivity with autoantigens is a consistent feature (Hussell et al., 1993; Greiner et al., 1994; Craig et al., 2010). The development of MALT lymphomas in general is associated with infection of the gastric mucosa with the bacterial pathogen H. pylori (Wotherspoon et al., 1993). The T cells have been shown to proliferate in response to the stimulating bacterial strains presented appropriately, but bizarrely there is no evidence that the $\mathrm{T}$ cell reactivity and B cell reactivity overlap in a way consistent with cognate interaction (Hussell et al., 1996). It is therefore possible that participation in human intestinal germinal center associated $\mathrm{B}$ cell responses is not dependent on cognate interactions. However, the lack of germinal centers in CD40-/- mice demonstrates that CD40 itself remains absolutely central to GALT germinal center initiation (Bergqvist et al., 2006).

\section{DO INNATE RECEPTORS HAVE ANY ROLE IN DRIVING THE HUMAN MUCOSAL IgA RESPONSE?}

They almost certainly do, as suggested by reports of increased invasive Salmonella and Shigella in patients with inborn errors in the signaling effectors IRAK-4 and MyD88 downstream of the TLRs (Picard et al., 2010). The absence of several enteric viral infections, may simply suggest that RIG-I-like helicases (RLRs) and NOD-like receptors (NLRs) may provide a compensatory role in MyD88 and IRAK-4 deficient individuals. Whether TLR, NLR, or RLRs operate any differently in the intestine compared to in peripheral systemic lymphoid tissues or tonsil is unknown.

The expression of innate TLR receptors by human and mouse B cells is very different, and it is not possible to draw any parallels in this respect. The most notable difference is the lack of TLR4 expression by human $\mathrm{B}$ cells and therefore inability to respond to LPS (Bourke et al., 2003; Wagner et al., 2004). In contrast to humans, LPS is the classic TI-1 B cell antigen that has been part of the murine B cell immunologists' toolbox for many years. The ability to respond to LPS by innate B cell subsets is a potentially important property in the gut and enabled identification of a functional link between murine peritoneal B1 and intestinal responses (Murakami et al., 1994).

Probably the most relevant and functionally important B cell innate receptor known in humans is TLR9. Whilst being extremely important to B cell function, is not known to have a specific role at mucosal surfaces. A recent study showed that there appeared to be no difference between the involvement of TLR9 in mucosal versus systemic responses (Barone et al., 2011). Interestingly, human tonsillar B cells are reported to undergo T-independent IgA production through an innate TLR3 BAFF dependent pathway (Xu et al., 2008). Whether intestinal infections with RNA viruses such as rotavirus or treatment of intestinal B cells with dsRNA trigger this TLR3 driven T-independent pathway is currently unknown.

\section{MIGHT GERMINAL CENTERS BE INVOLVED IN BOTH T CELL DEPENDENT AND T CELL INDEPENDENT IgA RESPONSES IN HUMANS?}

Although class switch recombination to IgA can be T cell independent or T cell dependent as described above (Zan et al., 1998; Litinskiy et al., 2002; Kaminski and Stavnezer, 2004), high rates of somatic hypermutation appear to be germinal center dependent (Bergqvist et al., 2006). Almost without exception, IgA plasma cells of healthy humans have high frequencies of mutations in IGHV, so that a germinal center independent contribution to the plasma cell population is not apparent (Boursier et al., 1999; Dunn-Walters et al., 2000; Di Niro et al., 2010). It is likely that the boundaries between $\mathrm{T}$ cell dependence and independence are blurred in vivo. In health, B cells are never truly remote from T cells or their lymphokines. The intestinal immune system is very flexible and the plasticity in the system probably testifies to its importance (Gibbons and Spencer, 2011). However, features that are observed when the system is compromised may not make a major contribution in health when the optimal paths and paths of least resistance would presumably be favored. T cell-independent responses are certainly possible, but it is not possible to gage the extent to which they actually occur in healthy humans.

\section{ARE THERE DIFFERENCES IN THE INDUCTION OF IgA RESPONSES THAT SEED THE SMALL BOWEL AND THE COLON?}

The GALT in human colon is different in structure to that in the small intestine. It tends to arise on the serosal side of the muscularis mucosae and to extend through a gap in the muscularis toward the surface epithelium forming a narrow FAE (O'Leary and Sweeney, 1986). The colonic FAE tends not to protrude into the intestinal lumen as FAE does in the small bowel (Spencer et al., 2009). Colonic GALT in humans was reported to tend not to include the large germinal centers observed in small intestinal GALT, though the same paper commented that the frequency of germinal centers in lymphoglandular complexes was more frequent in specimens with malignant growth (O'Leary and Sweeney, 1986).

The plasma cells that home to the colonic mucosa are known to have a greater tendency to migrate toward CCL28 through detection of this colonic epithelium derived chemokine by CCR10 (Kunkel et al., 2000). This contrasts with plasma cells destined for 
the small bowel that tend to express CCR9 that mediates movement toward CCL25 (Pan et al., 2000; Morteau et al., 2008). It is not known if these chemokine receptors that determine the site of extravasation of plasma cell precursors are induced differently in different microenvironments, though this would seem likely.

The human intestinal plasma cell population includes many clones of widely disseminated cells along the intestine. Early studies that visualized the spread of human plasma cell clones by microdissection of small numbers of cells identified clonal identity by sequencing IGHV saw that clones of plasma cells could span the small and large intestine, but that it was more common for clonally related groups of plasma cells to be identified in either small bowel or colon (Dunn-Walters et al., 1997; Holtmeier et al., 2000). This is consistent with the distribution of chemokine directed clones as described above. This pattern of plasma cell dissemination has now been elegantly confirmed through deep sequencing of the mouse IgA immunoglobulin repertoire. The elegant piece of work demonstrates the clonal spread of plasma cells, focused but not exclusive to either the small bowel or the large bowel (Lindner et al., 2012).

A difference between the plasma cells in human colon and those in the small intestine is the relatively high frequency of plasma cells secreting the IgA2 rather than IgA1 subclass of IgA. As discussed above (see Do the Events that Initiate the Human IgA Response Occur Exclusively in Gut-Associated Lymphoid Tissue?) it has been suggested that this switch to IgA2 may happen once cells have homed to the lamina propria (He et al., 2007). However, cells switched to IgA2 have been observed in colonic GALT (Barone and Spencer, 2010) and it is therefore possible that the switch to IgA2 and induction of CCR10 expression may both be features of induction of a colonic $B$ cell response. This inductive process might be promoted by the high colonic bacterial load (Kett et al., 1995). It is also possible that bacterial load could induce factors such as CCL28 that recruit effector cells propagated in the colonic GALT.

\section{IS THE HUMAN INTESTINAL IgA RESPONSE ANTIGEN SPECIFIC?}

IgA antibodies to polio were identified in intestinal secretions of immunized individuals, but not serum (Ogra and Karzon, 1969). This study was a major contributor to the establishment of mucosal immunology as a discipline. Polyspecific antibodies that bind to multiple antigens were also identified in secretions (Wijburg et al., 2006). However these studies did not allow the analysis of specificity at a single cell level. Since then, two developments have made a huge and precise contribution to our understanding of mucosal B cell specificities. The first is based on the engineered expression of immunoglobulin heavy and light chain sequences that had been expressed by intestinal plasma cells or their precursors (Weitkamp et al., 2005, 2006; Di Niro et al., 2010; Benckert et al., 2011). Such studies have permitted the in vitro expression of immunoglobulins and have identified that human intestinal plasma cells have pathogen specificity, but they are also reactive with a range of autoantigens in assays including the binding of antibodies to the $\mathrm{HEpC}$ cell line, normally used in the diagnosis of autoimmune diseases. The second method is dependent on the expression of surface immunoglobulins by intestinal plasma cells (Di Niro et al., 2010). This has permitted the quantification and isolation of cells binding fluorescence-tagged rotavirus antigens by flow cytometry, as well as the subsequent analysis of expressed protein following heavy and light chain gene sequencing. Antigen specificity within the human IgA response and persistent production of specific antibodies over time (Mesin et al., 2011) are encouraging observations that imply that effective intestinal vaccination is a totally realistic goal.

\section{IS LIGHT CHAIN DRIFTING A FEATURE OF THE IgA RESPONSE?}

Revision of light chains expressed IgA plasma cells is a feature of the human intestinal plasma cell response that is not widely appreciated and the factors regulating it are not known. Biases in gene rearrangements at the lambda loci of IgA plasma cells and their precursors are extreme and do not mirror the rearranged IGL gene profile of IgD+ mature naïve B cells (Su et al., 2008). A recent study into the origin of distinct memory $B$ cell subsets describe a drift from the expected $60: 40 \% \kappa: \lambda$ light chain isotype ratio in humans toward dramatically increased expression of lambda light chains (up to $80 \%$ Ig $\lambda+$ cells) by IgA+ memory B cells of the gut (Berkowska et al., 2011). This resonates the need for ongoing Ig gene rearrangements within a subset of cells required to continually diversify in response to the complex array of intestinal antigens. Each immunoglobulin heavy chain locus cannot rearrange more than once because the recombination signal sequences that flank the D segments are deleted by the initial rearrangement event. This is not a problem for the IGL rearrangements that do not involve D segments. The kappa locus can be inactivated by the kappa deleting element so that it is not always available for secondary rearrangements. The lambda locus however is not constrained in either of these ways and appears to be able to be sequentially activated and to permit drifting in the rearranged repertoire (Spencer et al., 2009). The detection of RAG genes in human GALT certainly supports this notion, though how this is regulated is unknown (Su et al., 2008).

\section{IS THERE LOCAL PROLIFERATION OF PLASMA CELL PRECURSORS IN THE HUMAN INTESTINAL LAMINA PROPRIA?}

Some early studies of rat intestine involved the surgical creation of isolated circles of intestine, so-called Thiry Vella loops. The isolated loops were separated from the rest of the intestine, through which the luminal contents would transit (Husband and Gowans, 1978). If antigen was introduced into the loops there was a tendency for antigen-producing cells to localize there and increase in number. Cells that homed to loops containing no specific challenge disappeared with time. This was interpreted as local proliferation of cells that homed to the lamina propria in response to the challenging antigen. It is now known however that such expansion was likely to have occurred in ILF within the loop. Cell division cannot be detected in isolated lamina propria plasma cells by immunohistochemical methods (Boursier et al., 2005). However, it has been claimed that clonal expansions of plasma cells within intestinal microenvironments is evident by identification of local groups of related IGHV sequences by PCR (Yuvaraj et al., 2009). In this model, the isolated IGHV sequences are identifiers of clones of 
cells. Other groups claim that such findings are a consequence of dissemination of large clones of cells throughout the intestine (Boursier et al., 2005).

A recent thorough and detailed analysis of mouse IgA plasma cell repertoire has modeled the distribution of plasma cell clones and asked whether this actual distribution fits a mathematical model that includes rounds of cell division after homing of plasma cell precursors to the lamina propria. This study concluded that the data best fits a model where plasma cell precursors home and differentiate either without or with very little cell division (Lindner et al., 2012). It is possible that cell division occurs during a narrow window of time or that it is very slow over a long time so that it is rarely observed. The expression of surface immunoglobulin by human intestinal plasma cells and their precursors certainly implies that they potentially remain receptive to external stimuli that could initiate cell activation (Di Niro et al., 2010).

\section{ARE HUMAN INTESTINAL IgA PLASMA CELLS LONG LIVED?}

A recent study by MacPherson's team using mice colonized by live bacteria with a finite life span (Hapfelmeier et al., 2010) has shown that intestinal plasma cell niches will fill according to current challenges and will be replaced depending on changes in the contents of the intestinal lumen. The question of plasma cell life span in humans was difficult to consider, until recent advances in expression of immunoglobulin variable region genes derived from plasma cells as immunoglobulin proteins. This enabled the detection of plasma cells secreting rotavirus specific antibodies when there was no recent history of rotavirus infection, clearly demonstrating long-term plasma cell survival (Di Niro et al., 2010;

\section{REFERENCES}

Barone, F., Patel, P., Sanderson, J., and Spencer, J. (2009). Gut-associated lymphoid tissue contains the molecular machinery to support T-cell dependent and T-cell-independent class switch recombination. Mucosal Immunol. 2, 495-503.

Barone, F., and Spencer, J. (2010). Gutassociated lymphoid tissue contains the molecular machinery to support T-cell-dependent and T-cellindependent class switch recombination. Mucosal Immunol. 3, 94-95.

Barone, F., Vossenkamper, A., Boursier, L., Su, W., Watson, A., John, S., Dunn-Walters, D. K., Fields, P., Wijetilleka, S., Edgeworth, J. D., and Spencer, J. (2011). IgA-producing plasma cells originate from germinal centers that are induced by Bcell receptor engagement in humans. Gastroenterology 140, 947-956.

Belnoue, E., Tougne, C., Rochat, A. F., Lambert, P. H., Pinschewer, D. D., and Siegrist, C. A. (2012). Homing and adhesion patterns determine the cellular composition of the bone marrow plasma cell niche. $J$. Immunol. 188, 1283-1291.

Benckert, J., Schmolka, N., Kreschel, C., Zoller, M. J., Sturm, A.,

Mesin et al., 2011). It remains unknown whether rotavirus infections might be subclinical and undetected, or if antigen might be retained, but nevertheless this insight is important because it shows that clinically relevant specific responses can be maintained.

Gene expression profiles of human intestinal plasma cells show them to have intermediate properties between short- and longlived plasma cell populations (Medina et al., 2003). A study of whole biopsies in organ culture have identified that intestinal plasma cells may have a longer lifespan in situ than in isolation (Mesin et al., 2011). APRIL can support plasma cell survival in bone marrow (Belnoue et al., 2012), and APRIL produced by macrophages and epithelial cells is likely to abundant in lamina propria (Barone et al., 2009). Blocking APRIL binding to its receptor blocks lamina propria plasma cell survival in in vitro organ cultures, implying that sustaining long-term plasma cell survival would be dependent on the local supportive microenvironment (Mesin et al., 2011).

\section{CONCLUSION}

IgA B cell responses to gut mucosal antigens: Do we know it all? The answer is clearly no. In this review we identified what we considered to be 12 important questions relating to this topic, but we were unable to answer the majority with any certainty. It is also highly unlikely that all researchers in this field would agree fully with our deductions. What is clear however is that the intestinal plasma cell response is geared toward generation of repertoire diversity in response to challenge from the luminal microbiota. Superimposing specificity and memory onto such a system is a major challenge for intestinal vaccine design.

B., and Wardemann, H. (2011). The majority of intestinal IgA+ and IgG+ plasmablasts in the human gut are antigen-specific. J. Clin. Invest. 121, 1946-1955.

Bergqvist, P., Gardby, E., Stensson, A., Bemark, M., and Lycke, N. Y. (2006). Gut IgA class switch recombination in the absence of CD40 does not occur in the lamina propria and is independent of germinal centers. J. Immunol. 177, 7772-7783.

Bergqvist, P., Stensson, A., Lycke, N. Y., and Bemark, M. (2010). T cellindependent IgA class switch recombination is restricted to the GALT and occurs prior to manifest germinal center formation. J. Immunol. 184, 3545-3553.

Berkowska, M. A., Driessen, G. J., Bikos, V., Grosserichter-Wagener, C., Stamatopoulos, K., Cerutti, A., He, B., Biermann, K., Lange, J. F., van der Burg, M., van Dongen, J. J., and van Zelm, M. C. (2011). Human memory B cells originate from three distinct germinal center-dependent and -independent maturation pathways. Blood 118, 2150-2158.

Blutt, S., and Conner, M. (2010). Viral induced $\mathrm{T}$ cell independent
B cell activation. J. Immunol. 184, 38.13.

through NOD1 regulates intestinal homeostasis. Nature 456, 507-510.

Blutt, S. E., Warfield, K. L., Estes, M. K., and Conner, M. E. (2008). Differential requirements for $\mathrm{T}$ cells in viruslike particle- and rotavirus-induced protective immunity. J. Virol. 82, 3135-3138.

Bourke, E., Bosisio, D., Golay, J. Polentarutti, N., and Mantovani, A. (2003). The toll-like receptor repertoire of human B lymphocytes: inducible and selective expression of TLR9 and TLR10 in normal and transformed cells. Blood 102, 956-963.

Boursier, L., Dunn-Walters, D. K., and Spencer, J. (1999). Characteristics of IgVH genes used by human intestinal plasma cells from childhood. Immunology 97, 558-564.

Boursier, L., Gordon, J. N., Thiagamoorthy, S., Edgeworth, J. D., and Spencer, J. (2005). Human intestinal IgA response is generated in the organized gut-associated lymphoid tissue but not in the lamina propria. Gastroenterology 128, 1879-1889.

Bouskra, D., Brézillon, C., Bérard, M., Werts, C., Varona, R., Boneca, I. G., and Eberl, G. (2008). Lymphoid tissue genesis induced by commensals
Brandtzaeg, P. (2009). Mucosal immunity: induction, dissemination, and effector functions. Scand. J. Immunol. 70, 505-515.

Brandtzaeg, P. (2010). Function of mucosa-associated lymphoid tissue in antibody formation. Immunol. Invest. 39, 303-355.

Brandtzaeg, P., Farstad, I. N., Johansen, F. E., Morton, H. C., Norderhaug, I. N., and Yamanaka, T. (1999). The Bcell system of human mucosae and exocrine glands. Immunol. Rev. 171, 45-87.

Brandtzaeg, P., and Pabst, R. (2004). Let's go mucosal: communication on slippery ground. Trends Immunol. 25, 570-577.

Casola, S., Otipoby, K. L., Alimzhanov, M., Humme, S., Uyttersprot, N., Kutok, J. L, Carroll, M. C., and Rajewsky, K. (2004). B cell receptor signal strength determines B cell fate. Nat. Immunol. 5, 317-327.

Cerutti, A. (2008a). Location, location, location: B-cell differentiation in the gut lamina propria. Mucosal Immunol. 1, 8-10. 
Cerutti, A. (2008b). The regulation of IgA class switching. Nat. Rev. Immunol. 8, 421-434.

Cerutti, A., Cols, M., Gentile, M., Cassis, L., Barra, C. M., He, B., Puga, I., and Chen, K. (2011). Regulation of mucosal $\operatorname{IgA}$ responses: lessons from primary immunodeficiencies. Ann. N. Y. Acad. Sci. 1238, 132-144.

Chabot, S., Wagner, J. S., Farrant, S., and Neutra, M. R. (2006). TLRs regulate the gatekeeping functions of the intestinal follicle-associated epithelium. J. Immunol. 176, 4275-4283.

Conley, M. E., and Delacroix, D. L. (1987). Intravascular and mucosal immunoglobulin A: two separate but related systems of immune defense? Ann. Intern. Med. 106, 892-899.

Cornes, J. S. (1965). Number, size, and distribution of Peyer's patches in the human small intestine: part I The development of Peyer's patches. Gut 6, 225-229.

Craig, V. J., Arnold, I., Gerke, C., Huynh, M. Q., Wündisch, T., Neubauer, A., Renner, C., Falkow, S., and Müller, A. (2010). Gastric MALT lymphoma B cells express polyreactive, somatically mutated immunoglobulins. Blood 115, 581-591.

Di Niro, R., Mesin, L., Raki, M., Zheng, N. Y., Lund-Johansen, F., Lundin, K. E., Charpilienne, A., Poncet, D., Wilson, P. C., and Sollid, L. M. (2010). Rapid generation of rotavirus-specific human monoclonal antibodies from smallintestinal mucosa. J. Immunol. 185, 5377-5383.

Di Niro, R., Mesin, L., Zheng, N. Y., Stamnaes, J., Morrissey, M., Lee, J. H., Huang, M., Iversen, R., du Pré, M. F., Qiao, S. W., Lundin, K. E., Wilson, P. C., and Sollid, L. M. (2012). High abundance of plasma cells secreting transglutaminase 2-specific IgA autoantibodies with limited somatic hypermutation in celiac disease intestinal lesions. Nat Med. 18, 441-445.

Dunn-Walters, D. K., Boursier, L., and Spencer, J. (1997). Hypermutation, diversity and dissemination of human intestinal lamina propria plasma cells. Eur. J. Immunol. 27, 2959-2964.

Dunn-Walters, D. K., Hackett, M., Boursier, L., Ciclitira, P. J., Morgan, P., Challacombe, S. J., and Spencer, J. (2000). Characteristics of human IgA and IgM genes used by plasma cells in the salivary gland resemble those used in duodenum but not those used in the spleen. J. Immunol. 164, 1595-1601.
Fagarasan, S., Kinoshita, K., Muramatsu, M., Ikuta, K., and Honjo, T. (2001) In situ class switching and differentiation to IgAproducing cells in the gut lamina propria. Nature 413, 639-643.

Farstad, I. N., Carlsen, H., Morton, H. C., and Brandtzaeg, P. (2000). Immunoglobulin A cell distribution in the human small intestine: phenotypic and functional characteristics. Immunology 101, 354-363.

Fayette, J., Dubois, B., Vandenabeele, S., Bridon, J. M., Vanbervliet, B., Durand, I., Banchereau, J., Caux, C., and Brière, F. (1997). Human dendritic cells skew isotype switching of CD40-activated naive B cells towards IgA1 and IgA2. J. Exp. Med. 185, 1909-1918.

Ferrari, S., Giliani, S., Insalaco, A., AlGhonaium, A., Soresina, A. R., Loubser, M., Avanzini, M. A., Marconi, M., Badolato, R., and Ugazio, A. G. (2001). Mutations of CD40 gene cause an autosomal recessive form of immunodeficiency with hyper IgM. Proc. Natl. Acad. Sci. U.S.A. 98, 12614-12619.

Franco, M. A., and Greenberg, H. B. (1997). Immunity to rotavirus in $\mathrm{T}$ cell deficient mice. Virology 238, 169-179.

Garside, P., Ingulli, E., Merica, R. R., Johnson, J. G., Noelle, R. J., and Jenkins, M. K. (1998). Visualization of specific $\mathrm{B}$ and $\mathrm{T}$ lymphocyte interactions in the lymph node. Science 281, 96-99.

Gibbons, D. L., and Spencer, J. (2011). Mouse and human intestinal immunity: same ballpark, different players; different rules, same score. Mucosal Immunol. 4, 148-157.

Gowans, J. L., and Knight, E. J. (1964). The route of re-circulation of lymphocytes in the rat. Proc. R. Soc. Lond. B Biol. Sci. 159, 257-282.

Greiner, A., Marx, A., Heesemann, J. Leebmann, J., Schmausser, B., and Müller-Hermelink, H. K. (1994). Idiotype identity in a MALT-type lymphoma and B cells in Helicobacter pylori associated chronic gastritis. Lab. Invest. 70, 572-578.

Hapfelmeier, S., Lawson, M. A., Slack, E., Kirundi, J. K., Stoel, M., Heikenwalder, M., Cahenzli, J., Velykoredko, Y., Balmer, M. L., Endt, K., Geuking, M. B., Curtiss, R. III, McCoy, K. D., and Macpherson, A. J. (2010). Reversible microbial colonization of germ-free mice reveals the dynamics of IgA immune responses. Science 328, 1705-1709.

Hardenberg, G., Planelles, L., Schwarte, C. M., van Bostelen, L., Le Huong, T., Hahne, M., and Medema, J. P. (2007).
Specific TLR ligands regulate APRIL secretion by dendritic cells in a PKRdependent manner. Eur. J. Immunol. 37, 2900-2911.

He, B., Xu, W., Santini, P. A., Polydorides, A. D., Chiu, A., Estrella, J., Shan, M., Chadburn, A., Villanacci, V., Plebani, A., Knowles, D. M., Rescigno, M., and Cerutti, A. (2007). Intestinal bacteria trigger $\mathrm{T}$ cell-independent immunoglobulin A(2) class switching by inducing epithelial-cell secretion of the cytokine APRIL. Immunity 26, 812-826.

Holtmeier, W., Hennemann, A., and Caspary, W. F. (2000). IgA and IgM $\mathrm{V}(\mathrm{H})$ repertoires in human colon: evidence for clonally expanded $B$ cells that are widely disseminated. Gastroenterology 119, 1253-1266.

Husband, A. J., and Gowans, J. L. (1978). The origin and antigen-dependent distribution of IgA-containing cells in the intestine. J. Exp. Med. 148, 1146-1160.

Hussell, T., Isaacson, P. G., Crabtree, J. E., Dogan, A., and Spencer, J. (1993). Immunoglobulin specificity of low grade B cell gastrointestinal lymphoma of mucosa-associated lymphoid tissue (MALT) type. Am. J. Pathol. 142, 285-292.

Hussell, T., Isaacson, P. G., Crabtree, J. E., and Spencer, J. (1996). Helicobacter pylori-specific tumour-infiltrating $\mathrm{T}$ cells provide contact dependent help for the growth of malignant B cells in low-grade gastric lymphoma of mucosa-associated lymphoid tissue. J. Pathol. 178, 122-127.

Isaacson, P. G., and Spencer, J. (1987). Malignant lymphoma of mucosa-associated lymphoid tissue. Histopathology 11, 445-462.

Ishikawa, H., Saito, H., Suzuki, K., Oida, T., and Kanamori, Y. (1999). New gut associated lymphoid tissue "cryptopatches" breed murine intestinal intraepithelial $\mathrm{T}$ cell precursors. Immunol. Res. 20, 243-250.

Kaminski, D. A., and Stavnezer, J. (2004). Antibody class switching: uncoupling $S$ region accessibility from transcription. Trends Genet. 20, 337-340.

Kanamori, Y., Ishimaru, K., Nanno, M. Maki, K., Ikuta, K., Nariuchi, H., and Ishikawa, H. (1996). Identification of novel lymphoid tissues in murine intestinal mucosa where clusters of c-kit+ IL-7R+ Thyl+ lymphohemopoietic progenitors develop. J. Exp. Med. 184, 1449-1459.

Kett, K., Baklien, K., Bakken, A., Kral, J. G., Fausa, O., and Brandtzaeg, P. (1995). Intestinal B-cell isotype response in relation to local bacterial load: evidence for immunoglobulin A subclass adaptation. Gastroenterology 109, 819-825.

Kett, K., and Brandtzaeg, P. (1987). Local IgA subclass alterations in ulcerative colitis and Crohn's disease of the colon. Gut 28, 1013-1021.

Kett, K., Brandtzaeg, P., Radl, J., and Haaijman, J. J. (1986). Different subclass distribution of IgA-producing cells in human lymphoid organs and various secretory tissues. J. Immunol. 136, 3631-3635.

Kroese, F. G., Butcher, E. C., Stall, A. M, and Herzenberg, L. A. (1989). A major peritoneal reservoir of precursors for intestinal IgA plasma cells. Immunol. Invest. 18, 47-58.

Kunkel, E. J., Campbell, J. J., Haraldsen, G., Pan, J., Boisvert, J., Roberts, A I., Ebert, E. C., Vierra, M. A., Goodman, S. B., Genovese, M. C., Wardlaw, A. J., Greenberg, H. B., Parker, C. M., Butcher, E. C., Andrew, D. P., Agace, W. W. (2000) Lymphocyte CC chemokine receptor 9 and epithelial thymus-expressed chemokine (TECK) expression distinguish the small intestinal immune compartment: epithelial expression of tissuespecific chemokines as an organizing principle in regional immunity. $J$. Exp. Med. 192, 761-767.

Levesque, M. C., Moody, M. A, Hwan, K-K., Marshall, D. J, Whitesides, J. F., Amos, J. D., Gurley, T. C., Allgood, S., Haynes, B. B., Vandergrift, N. A., Plonk, S., Parker, D. C., Cohen, M. S., Tomaras, G. D., Goepfert, P. A., Shaw, G. M., Schmitz, J. E., Eron, J. J., Shaheen, N. J., Hicks, C. B., Liao, H-X., Markowitz, M., Kelsoe, G., Margolis, D. M., and Haynes, B. F. (2009). Polyclonal B cell differentiation and loss of gastrointestinal tract germinal centers in the earliest stages of HIV-1 infection. PLoS Med. 6, e1000107. doi:10.1371/journal.pmed.1000107

Levine, M. M., Kotloff, K. L., Barry, E. M., Pasetti, M. F., and Sztein, M. B. (2007). Clinical trials of Shigella vaccines: two steps forward and one step back on a long, hard road. Nat. Rev. Microbiol. 5, 540-553.

Lindner, C., Wahl, B., Föhse, L., Suerbaum, S., Macpherson, A. J., Prinz, I., and Pabst, O. (2012). Age, microbiota, and $\mathrm{T}$ cells shape diverse individual IgA repertoires in the intestine. J. Exp. Med. 209, 365-377.

Litinskiy, M. B., Nardelli, B., Hilbert, D. M., He, B., Schaffer, A., Casali, P., and Cerutti, A. (2002). DCs induce CD40-independent immunoglobulin class switching through BLyS and APRIL. Nat. Immunol. 3, 822-829. 
McIntyre, T. M., Kehry, M. R., and Snapper, C. M. (1995). Novel in vitro model for high-rate IgA class switching. J. Immunol. 154, 3156-3161.

Medina, F., Segundo, C., Campos-Caro, A., Salcedo, I., García-Poley, A., and Brieva, J. A. (2003). Isolation, maturational level, and functional capacity of human colon lamina propria plasma cells. Gut 52, 383-389.

Mesin, L., Di Niro, R., Thompson, K. M., Lundin, K. E., and Sollid, L. M. (2011). Long-lived plasma cells from human small intestine biopsies secrete immunoglobulins for many weeks in vitro. J. Immunol. 187, 2867-2874.

Mobley, H. L. (1996). The role of Helicobacter pylori urease in the pathogenesis of gastritis and peptic ulceration. Aliment. Pharmacol. Ther. 10(Suppl. 1), 57-64.

Moghaddami, M., Cummins, A., and Mayrhofer, G. (1998). Lymphocytefilled villi: comparison with other lymphoid aggregations in the mucosa of the human small intestine. Gastroenterology 115, 1414-1425.

Morteau, O., Gerard, C., Lu, B., Ghiran, S., Rits, M., Fujiwara, Y., Law, Y., Distelhorst, K., Nielsen, E. M., Hill, E. D., Kwan, R., Lazarus, N. H., Butcher, E. C., and Wilson, E. (2008). An indispensable role for the chemokine receptor CCR10 in IgA antibody-secreting cell accumulation. J. Immunol. 181, 6309-6315.

Murakami, M., Tsubata, T., Shinkura, R., Nisitani, S., Okamoto, M., Yoshioka, H., Usui, T., Miyawaki, S., and Honjo, T. (1994). Oral administration of lipopolysaccharides activates B-1 cells in the peritoneal cavity and lamina propria of the gut and induces autoimmune symptoms in an autoantibody transgenic mouse. J Exp. Med. 180, 111-121.

Niess, J. H., Brand, S., Gu, X., Landsman, L., Jung, S., McCormick, B. A., Vyas, J. M., Boes, M., Ploegh, H. L., Fox, J. G., Littman, D. R., and Reinecker, H. C. (2005). CX3CR1mediated dendritic cell access to the intestinal lumen and bacterial clearance. Science 307, 254-258.

Ogra, P. L., and Karzon, D. T. (1969). Distribution of poliovirus antibody in serum, nasopharynx and alimentary tract following segmental immunization of lower alimentary tract with poliovaccine. J. Immunol. 102, 1423-1430.

O'Leary, A. D., and Sweeney, E. C. (1986). Lymphoglandular complexes of the colon: structure and distribution. Histopathology 10, 267-283.
Pabst, O., Bernhardt, G., and Forster, R. (2007). The impact of cell-bound antigen transport on mucosal tolerance induction. J. Leukoc. Biol. 82, 795-800.

Pabst, O., and Mowat, A. M. (2012). Oral tolerance to food protein. Mucosal Immunol. doi:10.1038/mi.2012.4. [Epub ahead of print].

Pan, J., Kunkel, E. J., Gosslar, U., Lazarus, N., Langdon, P., Broadwell, K., Vierra, M. A., Genovese, M. C., Butcher, E. C., and Soler, D. (2000). A novel chemokine ligand for CCR10 and CCR3 expressed by epithelial cells in mucosal tissues. J. Immunol. 165, 2943-2949.

Passwell, J. H., Ashkenasi, S., Harlev, E., Miron, D., Ramon, R., Farzam, N., Lerner-Geva, L., Levi, Y., Chu, C., Shiloach, J., Robbins, J. B., Schneerson, R., and Israel Shigella Group. (2003). Safety and immunogenicity of Shigella sonnei-CRM9 and Shigella flexneri type 2a-rEPAsucc conjugate vaccines in one-to fouryear old children. Pediatr. Infect. Dis. J. 22, 701-706.

Phalipon, A., Costachel, C., Grandjean, C., Thuizat, A., Guerreiro, C., Tanguy, M., Nato, F., Vulliez-Le Normand, B., Bélot, F., Wright, K., Marcel-Peyre, V., Sansonetti, P. J., and Mulard, L. A. (2006). Characterization of functional oligosaccharide mimics of the Shigella flexneri serotype 2a O-antigen: implications for the development of a chemically defined glycoconjugate vaccine. J. Immunol. 176, 1686-1694.

Picard, C., von Bernuth, H., Ghandil, P., Chrabieh, M., Levy, O., Arkwright, P. D., McDonald, D., Geha, R. S., Takada, H., Krause, J. C., Creech, C. B., Ku, C. L., Ehl, S., Maródi, L., Al-Muhsen, S., AlHajjar, S., Al-Ghonaium, A., DayGood, N. K., Holland, S. M., Gallin, J. I., Chapel, H., Speert, D. P., Rodriguez-Gallego, C., Colino, E., Garty, B. Z., Roifman, C., Hara, T., Yoshikawa, H., Nonoyama, S., Domachowske, J., Issekutz, A. C., Tang, M., Smart, J., Zitnik, S. E., Hoarau, C., Kumararatne, D. S., Thrasher, A. J., Davies, E. G., Bethune, C., Sirvent, N., de Ricaud, D., Camcioglu, Y., Vasconcelos, J., Guedes, M., Vitor, A. B., Rodrigo, C., Almazán, F., Méndez, M., Aróstegui, J. I., Alsina, L., Fortuny, C., Reichenbach, J., Verbsky, J. W., Bossuyt, X., Doffinger, R., Abel, L., Puel, A., and Casanova, J. L. (2010). Clinical features and outcome of patients with IRAK-4 and MyD88 deficiency. Medicine (Baltimore) 89, 403-425.
Pollard, A. J., Perrett, K. P., and Beverley, P. C. (2009). Maintaining protection against invasive bacteria with protein-polysaccharide conjugate vaccines. Nat. Rev. Immunol. 9 , 213-220.

Rasolofo-Razanamparany, V., CasselBeraud, A. M., Roux, J., Sansonetti, P. J., and Phalipon, A. (2001). Predominance of serotypespecific mucosal antibody response in Shigella flexneri-infected humans living in an area of endemicity. Infect. Immun. 69, 5230-5234.

Renz, H., Brandtzaeg, P., and Hornef, M. (2011). The impact of perinatal immune development on mucosal homeostasis and chronic inflammation. Nat. Rev. Immunol. 12, 9-23.

Rescigno, M., Urbano, M., Valzasina, B., Francolini, M., Rotta, G., Bonasio, R., Granucci, F., Kraehenbuhl, J. P., and Ricciardi-Castagnoli, P. (2001). Dendritic cells express tight junction proteins and penetrate gut epithelial monolayers to sample bacteria. Nat. Immunol. 2, 361-367.

Simon, J. K., Maciel, M. Jr., Weld, E. D., Wahid, R., Pasetti, M. F., Picking, W. L., Kotloff, K. L., Levine, M. M., and Sztein, M. B. (2011a). Antigenspecific IgA B memory cell responses to Shigella antigens elicited in volunteers immunized with live attenuated Shigella flexneri 2 a oral vaccine candidates. Clin. Immunol. 139, 185-192.

Simon, R., Tennant, S. M., Wang, J. Y., Schmidlein, P. J., Lees, A., Ernst, R. K., Pasetti, M. F., Galen, J. E., and Levine, M. M. (2011b). Salmonella enterica serovar enteritidis core $\mathrm{O}$ polysaccharide conjugated to $\mathrm{H}: \mathrm{g}, \mathrm{m}$ flagellin as a candidate vaccine for protection against invasive infection with S. enteritidis. Infect. Immun. 79, 4240-4249.

Schneider, T., Ullrich, R., and Zeitz, M. (1996). The immunologic aspects of human immunodeficiency virus infection in the gastrointestinal tract. Semin. Gastrointest. Dis. 7, 19-29.

Spencer, J., Barone, F., and DunnWalters, D. (2009). Generation of Immunoglobulin diversity in human gut-associated lymphoid tissue. Semin. Immunol. 21, 139-146.

Su, W., Gordon, J. N., Barone, F., Boursier, L., Turnbull, W., Mendis, S., Dunn-Walters, D. K., and Spencer, J. (2008). Lambda light chain revision in the human intestinal IgA response. J. Immunol. 181, 1264-1271.

Suzuki, K., and Fagarasan, S. (2009). Diverse regulatory pathways for
IgA synthesis in the gut. Mucosal Immunol. 2, 468-471.

Svenson, S. B., Nurminen, M., and Lindberg, A. A. (1979). Artificial Salmonella vaccines: O-antigenic oligosaccharide-protein conjugates induce protection against infection with Salmonella typhimurium. Infect. Immun. 1925, 863-872.

Tsuji, M., Suzuki, K., Kitamura, H., Maruya, M., Kinoshita, K., Ivanov, I. I., Itoh, K., Littman, D. R., and Fagarasan, S. (2008). Requirement for lymphoid tissue-inducer cells in isolated follicle formation and $\mathrm{T}$ cell-independent immunoglobulin A generation in the gut. Immunity 29, 261-271.

Turner, J. R. (2000). 'Putting the squeeze' on the tight junction: understanding cytoskeletal regulation. Semin. Cell Dev. Biol. 11,301-308.

VanCott, J. L., McNeal, M. M., Flint, J., Bailey, S. A., Choi, A. H., and Ward, R. L. (2001). Role for T cellindependent $\mathrm{B}$ cell activity in the resolution of primary rotavirus infection in mice. Eur. J. Immunol. 31, 3380-3387.

Wagner, M., Poeck, H., Jahrsdoerfer, B., Rothenfusser, S., Prell, D., Bohle, B. Tuma, E., Giese, T., Ellwart, J. W., Endres, S., and Hartmann, G. (2004). IL-12p70-dependent Th1 induction by human $\mathrm{B}$ cells requires combined activation with CD40 ligand and CpG DNA. J. Immunol. 172, 954-963.

Wei, M., Shinkura, R., Doi, Y., Maruya, M., Fagarasan, S., and Honjo, T. (2011). Mice carrying a knockin mutation of Aicda resulting in a defect in somatic hypermutation have impaired gut homeostasis and compromised mucosal defense. Nat. Immunol. 12, 264-270.

Weitkamp, J. H., Kallewaard, N. L., Bowen, A. L., Lafleur, B. J., Greenberg, H. B., and Crowe, J. E. Jr. (2005). VH1-46 is the dominant immunoglobulin heavy chain gene segment in rotavirusspecific memory B cells expressing the intestinal homing receptor alpha4beta7. J. Immunol. 174, 3454-3460.

Weitkamp, J. H., Lafleur, B. J., and Crowe, J. E. Jr. (2006). Rotavirusspecific CD5+ B cells in young children exhibit a distinct antibody repertoire compared with CD5- B cells. Hum. Immunol. 67, 33-42.

Wijburg, O. L, Uren, T. K., Simpfendorfer, K., Johansen, F. E., Brandtzaeg, P., and Strugnell, R. A. (2006). Innate secretory antibodies protect against 
natural Salmonella typhimurium infection. J. Exp. Med. 203, 21-26.

Williams, G. T. (1992). "The stomach: developmental and inflammatory conditions," in Oxford Text Book of Pathology, eds J. O.'D. McGee, P. G. Isaacson, and N. A. Wright (Oxford, New York, Tokyo: Oxford University Press).

Wotherspoon, A. C., Doglioni, C., Diss, T. C., Pan, L., Moschini, A., de Boni, M., and Isaacson, P. G. (1993). Regression of primary low-grade B-cell gastric lymphoma of mucosaassociated lymphoid tissue type after eradication of Helicobacter pylori. Lancet 342, 575-577.

Wotherspoon, A. C., Ortiz-Hidalgo, C., Falzon, M. R., and Isaacson,
P. G. (1991). Helicobacter pyloriassociated gastritis and primary Bcell gastric lymphoma. Lancet 338, 1175-1176.

Xu, W., Santini, P. A., Matthews, A. J., Chiu, A., Plebani, A., He, B., Chen, K., and Cerutti, A. (2008). Viral double-stranded RNA triggers Ig class switching by activating upper respiratory mucosa B cells through an innate TLR3 pathway involving BAFF. J. Immunol. 181, 276-287.

Yuvaraj, S., Dijkstra, G., Burgerhof, J. G., Dammers, P. M., Stoel, M., Visser, A., Kroese, F. G., and Bos, N. A. (2009). Evidence for local expansion of IgA plasma cell precursors in human ileum. J. Immunol. 183, 4871-4878.
Zan, H., Cerutti, A., Dramitinos, P., Schaffer, A., and Casali, P. (1998). CD40 engagement triggers switching to IgA1 and IgA2 in human B cells through induction of endogenous TGF-beta: evidence for TGF-beta but not IL-10-dependent direct $S \mathrm{mu} \rightarrow \mathrm{S}$ alpha and sequential $S \mathrm{mu} \rightarrow \mathrm{S}$ gamma, $\mathrm{S}$ gamma $\rightarrow \mathrm{S}$ alpha DNA recombination. J. Immunol. 161, 5217-5225.

Conflict of Interest Statement: The authors declare that the research was conducted in the absence of any commercial or financial relationships that could be construed as a potential conflict of interest.
Received: 20 February 2012; paper pending published: 15 March 2012; accepted: 17 April 2012; published online: 11 May 2012.

Citation: Spencer J, Klavinskis LS and Fraser LD (2012) The human intestinal IgA response; burning questions. Front. Immun. 3:108. doi: 10.3389/fimmu.2012.00108

This article was submitted to Frontiers in Mucosal Immunity, a specialty of Frontiers in Immunology.

Copyright (C) 2012 Spencer, Klavinskis and Fraser. This is an open-access article distributed under the terms of the Creative Commons Attribution Non Commercial License, which permits noncommercial use, distribution, and reproduction in other forums, provided the original authors and source are credited. 